\title{
Water quality and physicochemical parameters of outgoing waters in a pharmaceutical plant
}

\author{
Fella Hamaidi-Chergui ${ }^{1} \cdot$ Mohamed Brahim Errahmani $^{1,2}{ }^{10}$
}

Received: 20 February 2019 / Accepted: 23 September 2019 / Published online: 30 September 2019

(c) The Author(s) 2019

\begin{abstract}
This work has focused on a pharmaceutical plant waters and the environmental impact of its discharges. The Water Quality Index (WQI), the Organic Pollution Index (OPI) and the Sodium Adsorption Ratio (SAR) of incoming and outgoing waters were analyzed over seasonal variations for 5 months using classical and mathematical indices. Highly significant increases were observed at the output $(p<0.001)$ for electrical conductivity, alkalinity, calcium and sodium; very significant $(p<0.01)$ for nitrites, $\mathrm{COD}$ and $\mathrm{BOD}_{5}$; significant $(p<0.05)$ for turbidity, potassium and chlorides. The sulfates, nitrates, phosphates, ammonia, TSS, magnesium, aluminum, iron and manganese showed no significant differences $(p>0.05)$. These parameters remained high all over the study period except for the $\mathrm{BOD}_{5}$. The WQI was reported in input waters in the range 85.9-89.5 indicating water safe for domestic use, range 42.3-60.9 (medium to bad) in output waters highlighting the water pollution. The OPI highlighted waters with low-to-moderate pollution, essentially due to high levels of nitrites. The SAR was found in "medium-to-high" salinity and "low sodium" ranges, thus precautions required in soils but without significant global effects. The $\mathrm{COD} / \mathrm{BOD}_{5}$ ratio highlighted a wastewater sometimes difficultly biodegradable (ratio $>3$ ). In conclusion, often throughout all the study period, the outgoing waters were found with bad quality and non-negligible risks for soils; it is thus strongly advocated that these waters must undergo appropriate treatment to improve its physicochemical quality.
\end{abstract}

Keywords Physicochemical $\cdot$ Environmental parameters $\cdot$ Pollution $\cdot$ Reverse osmosis

\section{Introduction}

Water is a precious resource, threatened by intensive exploitation, increasing pollution of the reserves and the growing needs of a constantly increasing population. In Algeria, wastewater is generally sent to a treatment plant (WWTP) where it undergoes treatment, which mainly aims to eliminate organic matter (OM), suspended solids (SS) and more and more often nitrogen and/or phosphorus. These "treated" effluents are then discharged into the natural environment, into a watercourse or a river, which itself directly or indirectly feeds the underground aquifers used for drinking water supply.

Mohamed Brahim Errahmani

m.brahim.errahmani@univ-blida.dz

1 Department of Biology and Cellular Physiology, Faculty of Natural and Life Sciences, Blida 1 University, Blida, Algeria

2 Department of Chemistry, Faculty of Sciences, Blida 1 University, Blida, Algeria
The purpose of pollution control is to preserve the quality of water for human or agricultural use and to protect shellfish, finfish and wildlife (Munter 2000). The primary sources of water pollution are untreated municipal and industrial wastewater (Chau et al. 2015). It is currently established that pharmaceuticals are ubiquitous contaminants of wastewater effluents mostly occurring at sub-mg L ${ }^{-1}$ concentrations (Kim et al. 2007). Current wastewater treatment plant (WWTP) processes are designed to reduce levels of dissolved organic carbon, as well as nitrates and phosphates (Bouissou-Schurtz et al. 2014). Many "lower"- and "lowermiddle"-income countries use the wastewater they generate for irrigation of agricultural and horticultural land, and some countries use more than $40 \%$ of their municipal wastewater for this purpose (Lees et al. 2016).

An inconsistent level of disinfectant supply may be the source of an increased risk of biological instability in water distribution systems (Eissa 2017). In the pharmaceuticals industry, there are four main water treatment categoriesnamely process water treatment, ultrapure water treatment, wastewater treatment and sludge treatment (Pharmaceuticals 
Industry 2017). The treatment of wastewater containing aqua-toxic substances, discharged from pharmaceutical manufacturing facilities, can only be effective when it is not mixed with wastewater from other sources (European Commission 2003; Directive 2010/75/EU 2010).

Advanced wastewater treatment technologies as membrane filtration, nanofiltration, ultrafiltration and reverse osmosis can partially remove some chemicals and pharmaceutically active compounds (González et al. 2016). Some factories using one or the other of these technologies exist in the Maghreb and elsewhere in the world.

New water quality monitoring programs are being implemented that use LED-based sensors to meet a range of environmental standards (Venugopalan 2017). Gentili and Fick (2016) found out that algae cultivation can partially or totally remove pharmaceutical pollutants from urban wastewater, with reduction of inorganic nitrogen of $68 \%$ and total phosphorus by $56 \%$. The pharmaceutical industries are generating new substances, hence the urgent need to implement means of rapid assessment of possible risks for humans as well as for environmental ecosystems (Spitta et al. 2016).

Physicochemical properties are the foundation for pharmaceutical product development, manufacturing, and stability.

Research into bioremediation techniques has been implemented in the treatment of wastewater discharged by pharmaceutical plants which greatly improved waste disposal (Rana et al. 2014). The presence or absence of organic micro pollutants is a major factor in the acceptance of recycled water for indirect potable reuse (Escher et al. 2011).

Despite the treatments, these effluents remain the vectors of a large number of micropollutants, among which contaminants considered as "emerging", such as pharmaceuticals, very unevenly eliminated by conventional methods.
These substances, derived from the pharmaceutical industry, persist in treated or untreated wastewater; they denature the physicochemical parameters of water and contaminate aquatic environments (Buser and Müller 1998; Andreozzi et al. 2003; Kreuzinger et al. 2003) and thus the reservoirs in drinking water (Heberer 2002; Stamatelatou et al. 2003).

Many non-biodegradable organic compounds are found in low concentrations in rivers and groundwater. Because of their toxicity, their persistence, and their bio-accumulation, they are likely to generate nuisances even when they are released in very small quantities (Creanca 2007).

The aim of this work was the monitoring of the water quality degradation between the inlet and the outlet of a pharmaceutical plant and its possible impact on the environment.

\section{Materials and methods}

This work was performed in a pharmaceutical plant (Saidal Biotic, Bellevue, El Harrach, Algeria, Figs. 1 and 2). This water purification plant was created in 2003 with the participation of Christ Water Technology (Switzerland) in order to produce purified water that meets a certain number of required standards. It is managed by the Utilities Department, responsible for water treatment, boiler and compressor operation and maintenance of cooling and air conditioning equipment.

The waters supplying the pharmaceutical water production facilities (incoming waters) are drinking waters. However, they contain undesirable elements, hence the need to make them undergo additional treatments before there use in this type of unit.
Fig. 1 Location of the Biotic Saidal (Bellevue, El Harrach, Algeria)

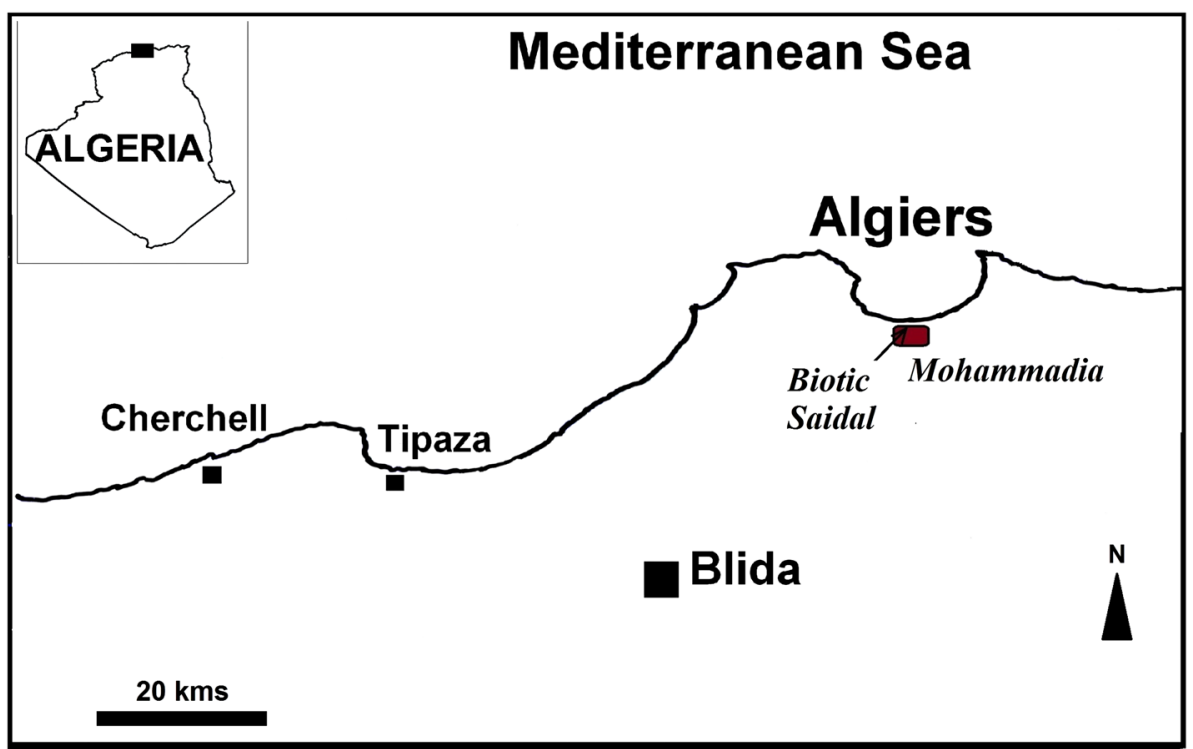


Fig. 2 The water purification plant

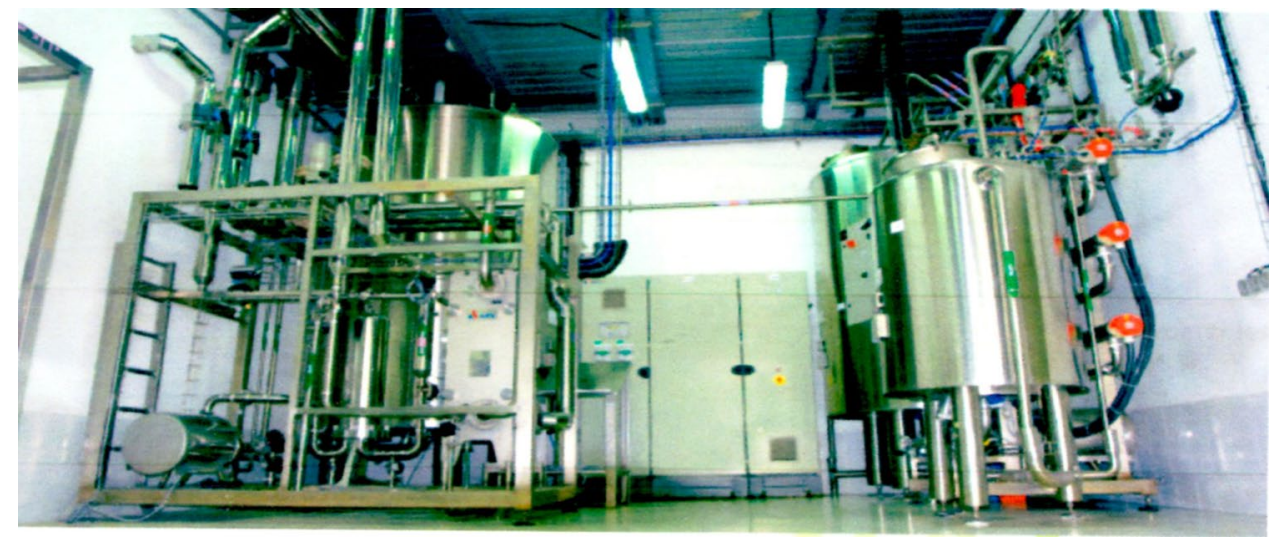

\section{Characteristics of the water processing chain}

To obtain a quality drug, the use of pure water is essential. The incoming waters are therefore subject to several stages of treatment before their use in the process of manufacturing drugs (Fig. 3).

The water samples were collected twice a month from February 28 to June 28, 2013, in 1-L bottles after repeated rinsing with water from the point of sampling. For heavy metals analyzes, sampling was done in acidified flasks. All of these samples refrigerated in a cooler at $6{ }^{\circ} \mathrm{C}$ during transport were brought directly to the laboratories.

The physicochemical quality of the incoming waters to the plant, the outgoing waters which are directly discharged outside the plant and the quality of water subjected to reverse osmosis used during the process of drugs manufacturing were analyzed at SEAAL Kouba (Société des Eaux et de l'Assainissement d'Alger).

The impact of the seasonal variations of several physicochemical parameters was also investigated for 5 months.

\section{Physicochemical analysis}

The electrical conductivity and the $\mathrm{pH}$ have been measured with Hach sensION pH meter and a Mettler Toledo conductimeter, respectively; the turbidity values were determined using Hach 2001 N.

The alkalimetric title, based on the concentrations of $\mathrm{HCO}_{3}{ }^{-}, \mathrm{CO}_{3}{ }^{2-}$ and $\mathrm{OH}^{-}$, was determined under fr T90-036 norm. The total suspended solids (TSS) were measured with filtration method under fiberglass ISO 11923. The nitrates and the aluminum were dosed on Hach DR5000 spectrophotometer. The chlorides levels were accessed using Mohr's method.

The $\mathrm{Na}^{+}, \mathrm{K}^{+}, \mathrm{Mn}^{2+}, \mathrm{Fe}^{2+}, \mathrm{Zn}^{2+}$ were determined by PerkinElmer flame AAS 800 spectrometry, the $\mathrm{Ca}^{2+}$ by EDTA titration. The $\mathrm{BOD}_{5}$ was measured on Hach BODTrak; the phosphates, the ammonium and the sulfates were measured using standard methods (Rodier et al. 2009).

\section{The WQI, the SAR and the OPI determinations}

The WQI proposed by Bascaran (1979) is calculated using the formula

$\mathrm{WQI}=\frac{k \sum_{i=1}^{n} C_{i} P_{i}}{\sum_{i=1}^{n} P_{i}}$

with $k=1=$ constant for apparently good quality water and lower than 1 for apparently polluted water, $C_{i}$ is the normalized value of the parameter, and $P_{i}$ is the relative weight assigned to each parameter (Table 1).

The WQI determination requires, at first, a normalization step where each of the ten variables is transformed into a 0-100 scale (0: minimal quality, 100: maximum quality).

The United States Salinity Laboratory Staff (1954) has introduced the Sodium Adsorption Ratio

$\mathrm{SAR}=\frac{\left[\mathrm{Na}^{+}\right]}{\sqrt{\frac{\left[\mathrm{Ca}^{2+}\right]+\left[\mathrm{Mg}^{2+}\right]}{2}}}$

where $\left[\mathrm{Na}^{+}\right],\left[\mathrm{Ca}^{2+}\right]$ and $\left[\mathrm{Mg}^{2+}\right]$ are the ion concentrations values in equivalents per million which is an important ratio concerning the effect of irrigation water on soils.

The OPI (Leclercq and Maquet 1987) is a saprobic index, i.e., for detection of organic pollution (Almeida 2001). This index is based on four parameters: $\mathrm{BOD}_{5}, \mathrm{NH}_{4}{ }^{+}, \mathrm{NO}_{2}{ }^{-}$and $\mathrm{PO}_{4}{ }^{3-}$ (Table 2) to which are assigned class values between 1 and 5 according to their levels in water.

The OPI is then calculated by the averaging of the four values. This index varies from 1 (strong organic pollution) to 5 (no organic pollution).

\section{Data treatment and statistical analysis}

The normality of the distributions and the homogeneity of data variances were tested using Kolmogorov-Smirnov

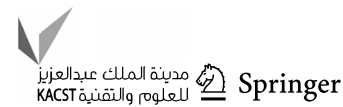


Fig. 3 The water treatment station

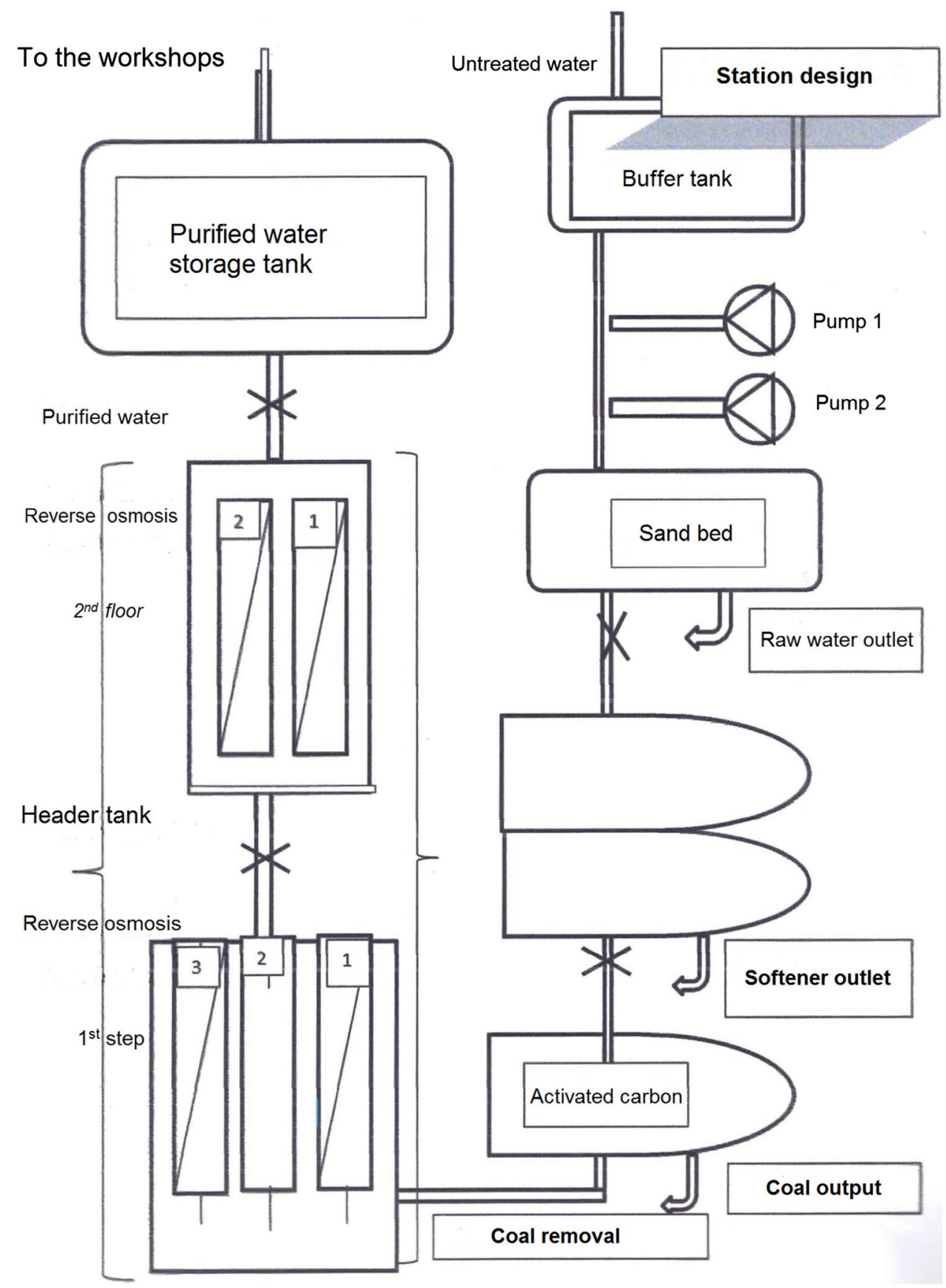

and Levene tests, respectively. The comparison of the incoming and outgoing waters parameters was performed with the period as covariable according to a general linear model (GLM) and an analysis of covariance (ANCOVA).

The Water Quality Index (WQI), the Sodium Adsorption Ration (SAR) and the Organic Pollution Index (OPI) had been determined during all the period of the experiment.

The statistical analysis was performed using Statistica 10 (Statsoft Inc., Tulsa, OK, USA). The results are given as mean \pm SE (SE: standard error). The differences were considered significant at $p<0.05$.

\section{Results and discussion}

\section{Physicochemical parameters}

The average parameters levels between incoming and outgoing waters were analyzed to assess the trophic status of the wastewater discharged by the plant in relation with 
Table 1 Relative weight and normalized values of the parameters entering in the calculation of WQI

\begin{tabular}{|c|c|c|c|c|c|c|c|c|c|c|c|c|}
\hline \multirow[t]{2}{*}{ Parameters } & \multirow[t]{2}{*}{$P_{\mathrm{i}}$} & \multicolumn{11}{|c|}{ Normalization factor $C_{i}$} \\
\hline & & 100 & 90 & 80 & 70 & 60 & 50 & 40 & 30 & 20 & 10 & 0 \\
\hline \multicolumn{13}{|c|}{ Range of analytical value } \\
\hline $\mathrm{pH}$ & 1 & 7 & $7-8$ & $7-8.5$ & $7-9$ & $6.5-7$ & $6-9.5$ & $5-10$ & $4-11$ & $3-12$ & $2-13$ & $1-14$ \\
\hline $\mathrm{EC}$ & 2 & $<0.75$ & $<1.00$ & $<1.25$ & $<1.50$ & $<2.00$ & $<2.50$ & $<3.00$ & $<5.00$ & $<8.00$ & $<12.0$ & $>12.0$ \\
\hline TSS & 4 & $<20$ & $<40$ & $<60$ & $<80$ & $<100$ & $<120$ & $<160$ & $<240$ & $<320$ & $<400$ & $>400$ \\
\hline Amm. & 3 & $<0.01$ & $<0.05$ & $<0.10$ & $<0.20$ & $<0.30$ & $<0.40$ & $<0.50$ & $<0.75$ & $<1.00$ & $<1.25$ & $>1.25$ \\
\hline $\mathrm{NO}_{2}^{-}$ & 2 & $<0.005$ & $<0.01$ & $<0.03$ & $<0.05$ & $<0.10$ & $<0.15$ & $<0.20$ & $<0.25$ & $<0.50$ & $<1.00$ & $>1.00$ \\
\hline $\mathrm{NO}_{3}^{-}$ & 2 & $<0.5$ & $<2.0$ & $<4.0$ & $<6.0$ & $<8.0$ & $<10.0$ & $<15.0$ & $<20.0$ & $<50.0$ & $<100$ & $>100$ \\
\hline $\mathrm{P}_{\mathrm{T}}$ & 1 & $<0.2$ & $<1.6$ & $<3.2$ & $<6.4$ & $<9.6$ & $<16.0$ & $<32.0$ & $<64.0$ & $<96.0$ & $<160$ & $>160$ \\
\hline COD & 3 & $<5$ & $<10$ & $<20$ & $<30$ & $<40$ & $<50$ & $<60$ & $<80$ & $<100$ & $<150$ & $>150$ \\
\hline $\mathrm{BOD}_{5}$ & 3 & $<0.5$ & $<2.0$ & $<3$ & $<4$ & $<5$ & $<6$ & $<8$ & $<10$ & $<12$ & $<15$ & $>15$ \\
\hline DO & 4 & $\geq=7.5$ & $>7.0$ & $>6.5$ & $>6.0$ & $>5.0$ & $>4.0$ & $>3.5$ & $>3.0$ & $>2.0$ & $>1.0$ & $<1.0$ \\
\hline$T$ & 1 & $21 / 16$ & $22 / 15$ & $24 / 14$ & $26 / 12$ & $28 / 10$ & $30 / 5$ & $32 / 0$ & $36 /-2$ & $40 /-4$ & $45 /-6$ & $>45 /<-6$ \\
\hline
\end{tabular}

$E C$ electrical conductivity $\left(\mathrm{mS} \mathrm{cm}^{-1}\right), \mathrm{T}\left({ }^{\circ} \mathrm{C}\right)$, all other values except $\mathrm{pH}$ in $\mathrm{mg} \mathrm{L}^{-1}$

Table 2 Classes for the organic pollution index (OPI) calculus

\begin{tabular}{lllll}
\hline Classes & $\begin{array}{l}\mathrm{BOD}_{5} \\
\mathrm{mg}-\mathrm{O}_{2} \mathrm{~L}^{-1}\end{array}$ & $\begin{array}{l}\mathrm{NH}_{4}^{+} \\
\mathrm{mg}-\mathrm{N} \mathrm{L}^{-1}\end{array}$ & $\begin{array}{l}\mathrm{NO}_{2}^{-} \\
\mu \mathrm{g}-\mathrm{N} \mathrm{L}^{-1}\end{array}$ & $\begin{array}{l}\mathrm{PO}_{4}{ }^{3-} \\
\mu \mathrm{g}-\mathrm{P} \mathrm{L}^{-1}\end{array}$ \\
\hline 5 & $<2$ & $<0.1$ & 5 & 15 \\
4 & $2-5$ & $0.1-0.9$ & $6-10$ & $16-75$ \\
3 & $5.1-10$ & $1.0-2.4$ & $11-50$ & $76-250$ \\
2 & $10.1-15$ & $2.5-6.0$ & $51-150$ & $251-900$ \\
1 & $>15$ & $>6$ & $>150$ & $>900$ \\
\hline
\end{tabular}

Organic pollution: very heavy $[1-2[$; heavy $[2-3[$; moderate $[3-4[$; low [4-4.6[; null [4.6-5]

the standard values of Food and Agriculture Organization (FAO) (Ayers and Westcot 1985).

The average temperatures were found significantly higher at the output (from $21.8 \pm 0.6$ to $23.8 \pm 0.6{ }^{\circ} \mathrm{C}$ ) increasing by $+2{ }^{\circ} \mathrm{C}(p=0.02)$. It is known the increase in temperature also increases the rate of microbial activity. The $\mathrm{pH}$ decreased significantly $(p=0.002)$ but remained in acceptable values, slightly basic in input $(8.1 \pm 0.1)$ and output waters $(7.4 \pm 0.1)$ but slightly acid for osmosed water $(6.5 \pm 0.3)$.

Highly significant increases $(p<0.001)$ were observed between incoming and outgoing waters (Fig. 4) for the parameters EC $\left(837 \pm 6-1409 \pm 14 \mu \mathrm{S} \mathrm{cm}^{-1},+68 \%\right)$, the alkalinity $\left(102 \pm 2-195 \pm 4 \mathrm{mg} \mathrm{L}^{-1},+91 \%\right)$, the total suspended solids (TSS) $\left(<2.0-1624 \pm 843 \mathrm{mg} \mathrm{L}^{-1},>800 \times\right.$ ), $\mathrm{Ca}^{2+}\left(80.9 \pm 2.1-136.3 \pm 6.9 \mathrm{mg} \mathrm{L}^{-1},+68 \%\right)$ and $\mathrm{Na}^{+}$ $\left(43.9 \pm 0.8-98.6 \pm 2.2 \mathrm{mg} \mathrm{L}^{-1},+125 \%\right)$. Some of these parameters increased near or more than the AG (Algerian standards): $\mathrm{Ca}^{2+}\left(75 \mathrm{mg} \mathrm{L}^{-1}\right), \mathrm{Na}^{+}\left(100 \mathrm{mg} \mathrm{L}^{-1}\right)$, or the WHO standards: EC $\left(180-1000 \mu \mathrm{S} \mathrm{cm}^{-1}\right)$, TSS $\left(30 \mathrm{mg} \mathrm{L}^{-1}\right)$.

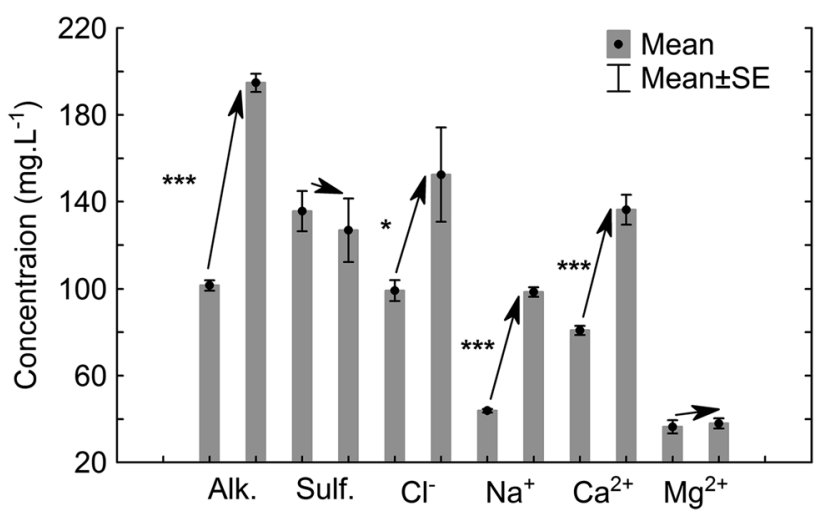

Fig. 4 Mean levels of some parameters in input and output waters ${ }^{*} p<0.05,{ }^{* *} p<0.01, * * * p<0.001$

The TSS which increase up to limit values for irrigation waters are an important parameter for the design of the wastewater treatment facility and the time needed to preserve the wastewater for primary treatment (Kavitha et al. 2012). It should be noted the over standard values for $\mathrm{Na}^{+}$levels of outgoing waters, source of an increase in the SAR.

These increases were also very significant $(p<0.01)$ for $\mathrm{NO}_{2}^{-}\left(<0.02-0.09 \pm 0.02 \mathrm{mg} \mathrm{L}^{-1},>4 \times\right), \mathrm{COD}(<30-57.5$ $\left.\pm 11.9 \mathrm{mg}_{-} \mathrm{O}_{2} \mathrm{~L}^{-1},>1.9 \times\right)$ and $\mathrm{BOD}_{5}(<0.50-48.0 \pm 14.5$ $\left.\mathrm{mg}-\mathrm{O}_{2} \mathrm{~L}^{-1},>96 \times\right)$. The increase in $\mathrm{BOD}_{5}$ is over the WHO standard ( $\left.30 \mathrm{mg} \mathrm{L}^{-1}\right)$.

A sharp rise in the level of COD or BOD in the water bodies increases their pollution (Effendi et al. 2015). The COD that doubles in outlet is a useful test in pinpointing toxic condition and the presence of biological resistant substances (Kavitha et al. 2012). The $\mathrm{BOD}_{5}$, that has reached values near one hundred times those in input, is linked to removal of oxygen by microorganisms in aerobic degradation of 
the dissolved organic matter in water over a 5-day period (Lokhande et al. 2011). The COD/BOD 5 ratio in outgoing waters was found equal to $2.3 \pm 0.6$ (range 0.4-5.1), highlighting a wastewater sometimes difficultly biodegradable. The range of the COD/BOD ratio is generally $2-3$, but for a 6-month period, it could have reach values up to 12 in wastewater from clinical laboratories of hospitals (Akin 2016). It is suggested, for a direct unloading on surface water after a pre-treatment for instance, $\mathrm{BOD}_{5} \leq 40 \mathrm{mg}-\mathrm{O}_{2} \mathrm{~L}^{-1}$ and $\mathrm{COD} /$ BOD $\leq 2.2$ (with TSS $\leq 80 \mathrm{mg} \mathrm{L}^{-1}$ and $\mathrm{NO}_{3}{ }^{-} \leq 20 \mathrm{mg} \mathrm{L}^{-1}$ ) (D. Lgs. 3 aprile 2006), values well beyond those found in this work.

The increases were significant $(p<0.05)$ for turbidity $\left(0.76 \pm 0.18-1.81 \pm 0.33 \mathrm{mg} \mathrm{L}^{-1},+138 \%\right)$ and chlorides $\left(99.2 \pm 4.8-152 \pm 22 \mathrm{mg} \mathrm{L}^{-1},+53 \%\right)$. There were no significant differences $(p>0.05)$ for the sulfates $\left(136 \pm 9-127 \pm 15 \mathrm{mg} \mathrm{L}^{-1}\right)$, the nitrates $\left(8.8 \pm 1.0-25.5 \pm 9.4 \mathrm{mg} \mathrm{L}^{-1}\right)$, the phosphates $\left(<0.09 \mathrm{mg} \mathrm{L}^{-1}\right)$, the ammonia $\left(<0.02 \mathrm{mg} \mathrm{L}^{-1}\right)$, the magnesium $\left(36.4 \pm 3.0-38.0 \pm 2.4 \mathrm{mg} \mathrm{L}^{-1}\right)$, the aluminum $(0.10 \pm$ $\left.0.01-0.08 \pm 0.05 \mathrm{mg} \mathrm{L}^{-1}\right)$, the iron $\left(<0.05 \mathrm{mg} \mathrm{L}^{-1}\right)$ and the manganese $\left(<0.05 \mathrm{mg} \mathrm{L}^{-1}\right)$; only $\mathrm{K}^{+}$decreased significantly $\left(2.14 \pm 0.16-1.56 \pm 0.14 \mathrm{mg} \mathrm{L}^{-1},-27 \%, p=0.01\right)$, and $\mathrm{Zn}$ levels reached $0.09 \pm 0.04 \mathrm{mg} \mathrm{L}^{-1}$.

Nitrogen and phosphorus are the main factors leading to water blooms, but also important indices for the evaluation of the reservoirs' degrees of eutrophication (Nazeer et al. 2014), and high levels of $\mathrm{Mg}^{2+}$ and $\mathrm{Cl}^{-}$may cause harmful effects in irrigation waters. Mustufa et al. (2013) using bio-filtration wastewater treatment have found a decrease in $\mathrm{K}^{+}$between effluent and influent waters in range 6.0 to $36.6 \%$ with gypsum biofilter and $42.2-60.5 \%$ with phosphate biofilter.

On the other hand, if we limit ourselves to only outgoing waters parameters, there were no significant changes over time from February to June, except for $\mathrm{BOD}_{5}$ which decreased from $97.4 \mathrm{mg}-\mathrm{O}_{2} \mathrm{~L}^{-1}$ in cold season to $9.3 \mathrm{mg}-\mathrm{O}_{2} \mathrm{~L}^{-1}$ in warm season. In this work, the seasonal impacts were not totally taken into account; the experiments held just between last February and middle of June, knowing that significant differences may be observed for a parameter between rainy and dry season (Estrada-Arriaga et al. 2016). The seasonal effects can slightly temperate the previous results because $\mathrm{P}$ limitation frequently occurs in the spring, whereas $\mathrm{N}$ is often limited during the summer months (Chen et al. 2016).

\section{WQI}

The WQI is an available tool to approximate the quality of water and facilitate the work of decision makers by grouping and analyzing numerous parameters with a single numerical classification system (de La Mora-Orozco et al. 2017).

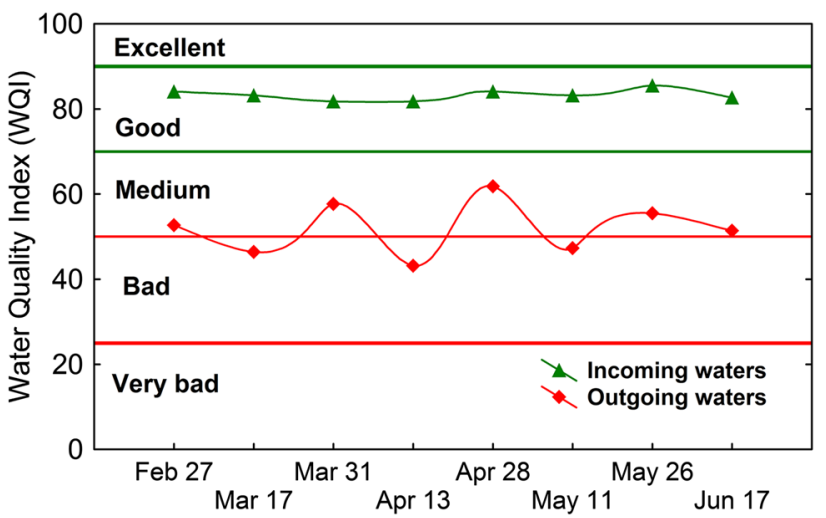

Fig. 5 Water Quality Index (WQI) of incoming and outgoing waters in the pharmaceutical plant from February 27 to June 17, 2013

Table 3 Water Quality Index (WQI) of the outgoing waters in the pharmaceutical plant from February 27 to June 17, 2013

\begin{tabular}{lll}
\hline Date & WQI range & WQI rating \\
\hline Feb 27 & 52.7 & Medium \\
Mar 17 & 46.4 & Bad \\
Mar 31 & 57.7 & Medium \\
Apr 13 & 43.2 & Bad \\
Apr 28 & 61.8 & Medium \\
May 11 & 47.3 & Bad \\
May 26 & 55.5 & Medium \\
Jun 17 & 51.4 & Medium \\
\hline
\end{tabular}

This index was at the first time proposed by Horton (1965). The use of water quality indices (WQI) simplifies the presentation of results of any analysis related to a water body (Damodhar and Reddy 2013).

The index provides a user-friendly interface that links each data element to integrated relationships found in scientific literature (USDA 2017); it can be considered as a reliable indicator for the classification of the waters (Hernandez-Romero et al. 2004). The WQI summarizes the information from a large number of parameters in a single value, allowing time trends to be examined on a single site (Lindbo and Miller 2012).

In this work, the WQI, based on 10 parameters: $\mathrm{T}, \mathrm{pH}$, $\mathrm{EC}$, nitrates, nitrites, phosphates, ammonia, $\mathrm{COD}, \mathrm{BOD}_{5}$ and TSS, has summarized the information on water quality overall parameters over the period of experiment.

The water quality rating for the different ranges of WQI is: very bad (range 0-25), bad (25-50), medium (50-70), good (70-90) and excellent (90-100).

The calculated values for incoming waters (Fig. 5) were found between 81.8 and 85.5 indicating a good WQI rating, but in medium-to-bad WQI rating for the outgoing wastewater (Table 3), indicating its high level of pollution. 


\section{SAR}

The water hardness increases with the $\mathrm{Na}^{+}$and $\mathrm{Ca}^{2+}$ concentrations, which form insoluble minerals in the presence of high carbonates (Rabeiy 2017). Based on the levels of $\mathrm{Na}^{+}$, $\mathrm{Ca}^{2+}$ and $\mathrm{Mg}^{2+}$, the SAR is actually an important parameter for determining the suitability of groundwater for irrigation because it is a measure of alkali/sodium hazard to crops (Ramesh and Elango 2012).

High sodium concentration leads to development of alkaline soil and is difficult to take into agricultural production due to low infiltration capacity and rain water stagnation (Nag and Suchetana 2016). The irrigation water with a high EC will tend to have fewer problems with infiltration than a low EC water (Cahn 1985), and high levels of bicarbonate may have less calcium available to counteract the dispersion effects of sodium.
At high levels of sodium relative to divalent cations in the soil solution, under low total salt concentration and high $\mathrm{pH}$, the permeability of the soil is reduced and the surface becomes more crusted, its ability to transmit water is severely reduced by excessive sodicity (FAO 1992).

Based on the SAR in relation with the EC, the incoming waters were found with high salinity and low sodium hazard (area C3S1 Figs. 6 and 7) with a mean of EC at $837 \pm 6$ $\mu \mathrm{S} \mathrm{cm}^{-1}$ (range 818-865) and $1.02 \pm 0.03\left(\mathrm{meq} \mathrm{L}^{-1}\right)^{1 / 2}$ for SAR (range 0.94-1.16), which indicated water suitable for irrigation without particular danger.

The outgoing waters were with relatively higher EC levels $\left(1409 \pm 14 \mu \mathrm{S} \mathrm{cm}^{-1}\right.$, range 1322-1347) and SAR $\left(1.93 \pm 0.05\left(\mathrm{meq} \mathrm{L}^{-1}\right)^{1 / 2}\right.$, range 1.67-2.07), but remaining in the same area.

Meanwhile, some precautions are required in soils with restricted drainage.
Fig. 6 Quality of the incoming (in green) and outgoing waters (in red) in relation to salinity and sodium waters in the pharmaceutical plant from February 27 to June 17, 2013

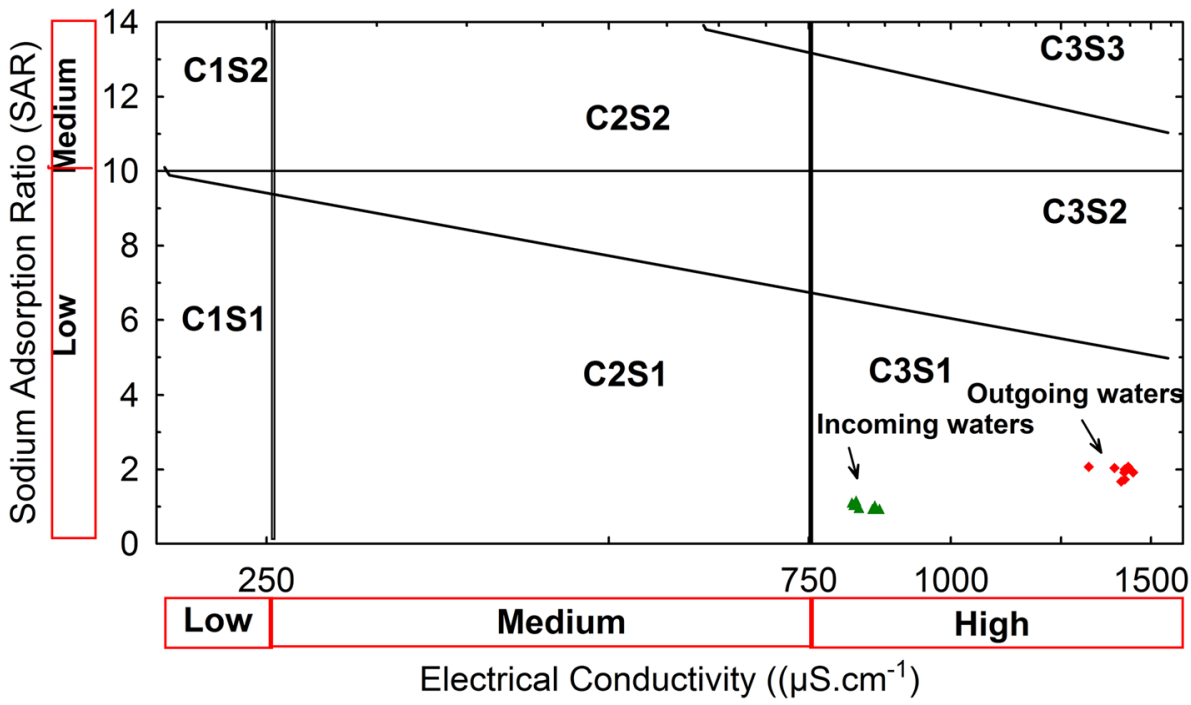

Fig. 7 Relationship between the Sodium Adsorption Ratio (SAR) and the electrical conductivity (EC) of the incoming and outgoing waters in the pharmaceutical plant from February 27 to June 17, 2013

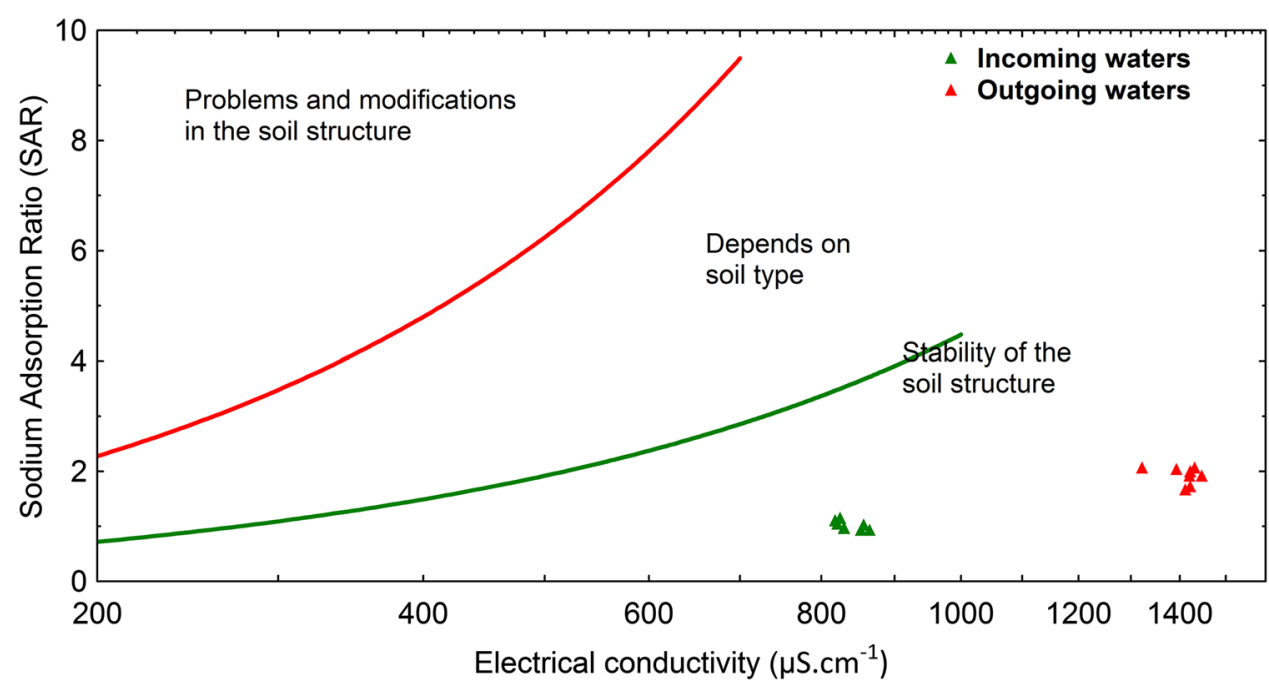


Table 4 Organic pollution of the waters in the pharmaceutical plant from February 27 to June 17,2013

\begin{tabular}{|c|c|c|c|c|c|c|c|c|}
\hline & \multirow[t]{2}{*}{$\mathrm{BOD}_{5}\left(\mathrm{mg}-\mathrm{O}_{2} \mathrm{~L}^{-1}\right)$} & \multirow{2}{*}{$\begin{array}{l}\mathrm{NO}_{2}^{-} \\
\left(\mu \mathrm{g}-\mathrm{N} \mathrm{L}^{-1}\right)\end{array}$} & \multicolumn{4}{|c|}{ Classes } & \multirow{2}{*}{$\begin{array}{l}\text { OPI } \\
\text { Mean }\end{array}$} & \multirow{2}{*}{$\begin{array}{l}\text { Organic } \\
\text { Pollution }\end{array}$} \\
\hline & & & $\mathrm{BOD}_{5}$ & $\mathrm{NH}_{4}^{+}$ & $\mathrm{NO}_{2}^{-}$ & $\mathrm{PO}_{4}^{3-}$ & & \\
\hline Incoming & $0.25-0.50$ & $0-6$ & 5 & 5 & 4 & 4 & 4.5 & Low \\
\hline Osmosed water & $0.25-0.50$ & $0-6$ & 5 & 5 & 4 & 4 & 4.5 & Low \\
\hline Outgoing Feb 27 & 97.370 & 27 & 1 & 5 & 3 & 4 & 3.3 & Moderate \\
\hline Outgoing Mar 17 & 95.0 & 37 & 1 & 5 & 3 & 4 & 3.3 & Moderate \\
\hline Outgoing Mar 31 & 34.2 & 15 & 1 & 5 & 3 & 4 & 3.3 & Moderate \\
\hline Outgoing Apr 13 & 96.2 & 15 & 1 & 5 & 3 & 4 & 3.3 & Moderate \\
\hline Outgoing Apr 28 & 28.9 & 21 & 1 & 5 & 3 & 4 & 3.3 & Moderate \\
\hline Outgoing May 11 & 11.6 & 15 & 2 & 5 & 3 & 4 & 3.5 & Moderate \\
\hline Outgoing May 26 & 11.3 & 73 & 2 & 5 & 2 & 4 & 3.3 & Moderate \\
\hline Outgoing Jun 17 & 9.3 & 9 & 3 & 5 & 4 & 4 & 4.0 & Low \\
\hline
\end{tabular}

OPI very heavy (1.0-1.9); heavy (2.0-2.9); moderate (3.0-3.9); low (4.0-4.5); null (4.6-5.0)
There is, indeed, between the incoming and the outgoing waters an increase of $68 \%$ of the EC and $89 \%$ for the SAR. It has been demonstrated that there was a negative correlation between yield and soil SAR (Rasouli et al. 2013) and, to date, it is confirmed that there is a direct relationship between the soil water content and the variables related to the liquid water balance in the vegetation covers (Gómez-Giráldez et al. 2014).

That is why, over time, it can be expected negative effects on the soils.

\section{OPI}

This index can be used for detection of organic pollution or to assess the sediment quality using sediment quality guidelines (Zhang et al. 2017). Among the important factors $\left(\mathrm{Na}^{+}, \mathrm{Cl}^{-}, \mathrm{pH}, \mathrm{HCO}^{3-}, \mathrm{EC}, \mathrm{SAR}\right.$ and TDS) concerning the quality of irrigation waters, the SAR has the maximum weight factor (Misaghi et al. 2017).

The results (Table 4) showed a low OPI for incoming and reverse osmosis waters. This index has mostly remained in range corresponding to moderate pollution for the outgoing waters. Some high levels of nitrites participated in the decrease in the index, corresponding to more polluted waters, but essentially due to high levels of $\mathrm{BOD}_{5}$ (up to 15 times the standard values).

The nitrites concentrations, punctually up to eight times the standard values $\left(73 \mu \mathrm{g}-\mathrm{N} \mathrm{L}^{-1}=0.24 \mathrm{mg} \mathrm{L}^{-1}\right.$ of $\mathrm{NO}_{2}{ }^{-}$in last of May), are generally indicative of industrial effluents and often associated with unsatisfactory microbiological quality of water (Chapman 1996).

It should be noted that the water quality might be affected by various organic substances, even in situations where the concentrations of individual components were below their NOEC (no observed effect concentration) (Faust et al. 2003).

\section{Conclusion}

The results of the present work showed that the outgoing waters from the pharmaceutical plant had presented significant increases in parameters as $\mathrm{EC}, \mathrm{COD}, \mathrm{BOD}_{5}$, alkalinity, $\mathrm{Na}^{2+}$ or $\mathrm{Ca}^{2+}$ making the water often with bad quality and non-negligible risks for soils. These high levels in the outgoing waters remained stable without sensible changes all over the period of experiment, which implies a sustained and constant pollution. The treatment methods usually used must be seriously improved to bring down the different parameters to acceptable levels at the output of the plant.

Acknowledgements We wish to acknowledge the personnel of the laboratory of "Société des Eaux et de l'Assainissement d'Alger" (SEAAL, Kouba, Algiers) for their help during this experiment

Open Access This article is distributed under the terms of the Creative Commons Attribution 4.0 International License (http://creativeco mmons.org/licenses/by/4.0/), which permits unrestricted use, distribution, and reproduction in any medium, provided you give appropriate credit to the original author(s) and the source, provide a link to the Creative Commons license, and indicate if changes were made.

\section{References}

Akin BS (2016) Contaminant properties of hospital clinical laboratory wastewater: a physiochemical and microbiological assessment. J Environ Prot 7:635-642

Almeida SFP (2001) Use of diatoms for freshwater quality evaluation in Portugal. Limnetica 20(2):205-213

Andreozzi R, Raffaele M, Nicklas P (2003) Pharmaceuticals in STP effluents and their solar photodegradation in aquatic environment. Chemosphere 50:1319-1330

Ayers RS, Westcot DW (1985) Water quality for agriculture, food and agriculture organization, irrigation and drainage paper 29 , Rev 1. Rome, Italy 
Bascaron M (1979) Establishment of a methodology for the determination of water quality. Bol Inf Medio Ambient 9:30-51, CIMA, MOPU, Madrid. In: Lumb A, Sharma TC, Bibeault JF (2011) A review of genesis and evolution of water quality Index (WQI) and some future directions. Water Qual Expo Health 3:11-24. https:// doi.org/10.1007/s12403-011-0040-0

Bouissou-Schurtz C, Houeto P, Guerbet M, Bachelot M, Casellas C, Mauclaire AC, Panetier P, Delval C, Masset D (2014) Ecological risk assessment of the presence of pharmaceutical residues in a French national water survey. Regul Toxicol Pharm 69:296-303

Buser HR, Müller MD (1998) Occurrence of the pharmaceutical drug clofibric acid and the herbicide Mecoprop in various Swiss lakes and the North Sea. Environ Sci Technol 32:188-192

Cahn M (1985) Evaluating salinity in irrigation water, irrigation and water resource advisor, monterey county UCCE, table adapted from FAO irrigation and drainage paper 29

Chapman D (1996) Water quality assessments: a guide to the use of biota, and water environmental monitoring, 2nd E. UNESCO, WHO, and UNEP. E and FN Spon. London, UK

Chau G, Sebesvari Z, Amelung W, Renaud G (2015) Pesticide pollution of multiple drinking water sources in the Mekong Delta, Vietnam: evidence from two provinces. Environ Sci Pollut R 22:9042-9058. In: Le Luu T (2017) Remarks on the current quality of groundwater in Vietnam. Environ Sci Pollut Res. https://doi. org/10.1007/s11356-017-9631-z

Chen CW, Ju YR, Chen CF, Dong CD (2016) Evaluation of organic pollution and eutrophication status of Kaohsiung Harbor, Taiwan. Int Biodeter Biodegrad 113:318-324

Creanca CM (2007) Procédé AD-OX d'élimination de polluants organiques non biodégradables (par adsorption puis oxydation catalytique). Thèse de Doctorat, Institut National Polytechnique de Toulouse, France

Damodhar U, Reddy MV (2013) Impact of pharmaceutical industry treated effluents on the water quality of river Uppanar, South east coast of India: a case study. Appl Water Sci 2013:501-514. https ://doi.org/10.1007/s13201-013-0098-X

de la Mora-Orozco C, Lopez HF, Rubio-Arias H, Chavez-Duran A, Ochoa-Rivero J (2017) Developing a water quality index (WQI) for an irrigation dam. Int J Environ Res Public Health 14(5):439. https://doi.org/10.3390/ijerph14050439

D. Lgs. 3 aprile (2006) Norme in Materia Ambientale. Gazzetta Ufficiale. n. 152. n. 88. Suppl. Ord. n. 96 del 14 aprile 2006. In: Carraro E, Bonetta Si, Bertino C, Lorenzi E, Bonetta Sa, Gilli G (2016) Hospital effluents management: Chemical, physical, microbiological risks and legislation in different countries. J Environ Manage 168:185-199

Directive 2010/75/EU (2010) of the European Parliament and of the Council of 24 November 2010 on industrial emissions (Integrated Pollution Prevention and Control) (Recast). In: Martz M (2012) Effective wastewater treatment in the pharmaceutical industry. Pharmaceutical Engineering, ISPE, 32(6). http://www.Pharmaceut icalEngineering.org

Effendi H, Wardiatno Y, Romanto (2015) Water quality status of Ciambulawung River, Banten Province, based on pollution index and NSF-WQI. Proc Environ Sci 24:228-237

Eissa ME (2017) Determination of the microbiological quality of feed city water to pharmaceutical facility: distribution study and statistical analysis. Athens J Sci 4(2):143-160

Escher BI, Lawrence M, Macova M, Mueller JF, Poussade Y, Robillot C, Roux A, Gernjak W (2011) Evaluation of contaminant removal of reverse osmosis and advanced oxidation in full-scale operation by combining passive sampling with chemical analysis and bioanalytical tools. Environ Sci Technol 45:5387-5394

Estrada-Arriaga EB, Cortés-Muñoz JE, González-Herrera A et al (2016) Assessment of full-scale biological nutrient removal systems upgraded with physico-chemical processes for the removal of emerging pollutants present in wastewaters from Mexico. Sci Total Environ 571:1172-1182

European Commission (2003) Integrated pollution prevention and control reference document on best available techniques in common wastewater and waste gas treatment/management systems in the chemical sector. In: Martz M (2012) Effective wastewater treatment in the pharmaceutical industry. Pharma Eng ISPE 32(6) www.PharmaceuticalEngineering.org

FAO (1992) The use of saline waters for crop production. Irrigation and drainage paper 48, FAO, Rome. In: Khan MB, Khan MY, Khan KI, Akbar MT (2012) Quality of ground water for irrigation of tehsil Kot Adu, District Muzaffar Garh Punjab. Pakistan World Rural Observations 4:2

Faust M, Altenburger R, Backhaus T, Blanck H, Boedeker W, Gramatica P, Hamer V, Scholze M, Vighi M, Grimme LH (2003) Joint algal toxicity of 16 dissimilarly acting chemicals is predictable by the concept of independent action. Aquat Toxicol 63:43-63

Gentili FG, Fick J (2016) Algal cultivation in urban wastewater: an efficient way to reduce pharmaceutical pollutants. J Appl Phycol 29(1):255-262. https://doi.org/10.1007/s10811-016-0950-0

Gómez-Giráldez PJ, Aguilar C, Polo MJ (2014) Natural vegetation covers as indicators of the soil water content in a semiarid mountainous watershed. Ecol Indic 46:524-535

González O, Bayarri B, Acena J, Pérez S, Barceló D (2016) Treatment technologies for wastewater reuse: Fate of contaminants of emerging concern. In: Fatta-Kassinos D, Dionysiou DD, Kümmerer K (eds) Advanced treatment technologies for urban wastewater reuse: the handbook of environmental chemistry, vol 45, pp 5-37. https://doi.org/10.1007/698_2015_363

Heberer T (2002) Occurrence, fate and removal of pharmaceutical residues in the aquatic environment: a review of the recent research data. Toxicol Lett 131:5-17

Hernandez-Romero AH, Tovilla-Hernandez C, Malo EA, BelloMendoza R (2004) Water quality and presence of pesticides in a tropical coastal wetland in southern Mexico. Mar Pollut Bull 48:1130-1141

Horton RK (1965) An index number system for rating water quality. Water Pollut Control Fed 37:300-306

Industry Pharmaceuticals (2017) Water \& wastewater treatment. Waterworld, PennWell Corporation, Tulsa

Kavitha RV, Murthy VK, Makam R, Asith KA (2012) Physico-chemical analysis of effluents from pharmaceutical industry and its efficiency study. Int J Eng Res Appl 2(2):103-110

Kim SD, Cho J, Kim IS, Vanderford BJ, Snyder SA (2007) Occurrence and removal of pharmaceuticals and endocrine disruptors in South Korean surface, drinking, and waste waters. Water Res 41:1013-1021

Kreuzinger N, Clara M, Strenn B, Vogel B (2003) Investigation on the behaviour of selected pharmaceuticals in the groundwater after infiltration of treated wastewater. Water Sci Technol 50:221-228

Leclercq L, Maquet B (1987) Deux nouveaux indices chimiques et diatomiques de qualité d'eau courante. Application au Samson et à ses affluents (bassin de la Meuse belge). Comparaison avec d'autres indices chimiques, biocénotiques et diatomiques. Institut Royal des Sciences Naturelles de Belgique, document de travail 28:113

Lees K, Fitzsimons M, Snape J, Tappin A, Comber S (2016) Pharmaceuticals in soils of lower income countries: physico-chemical fate and risks from wastewater irrigation. Environ Int 94:712-723

Lindbo T, Miller J (2012) Student watershed research project SWRP, clean water services

Lokhande RS, Singare PU, Pimple DS (2011) Study on physico-chemical parameters of waste water effluents from Taloja industrial area of Mumbai, India. Int J Ecosyst 1(1):1-9

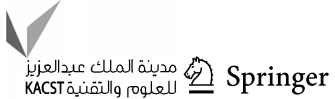


Misaghi F, Delgosha F, Razzaghmanesh M, Myers B (2017) Introducing a water quality index for assessing water for irrigation purposes: a case study of the Ghezel Ozan River. Sci Total Environ 589:107-116

Munter R (2000) Industrial wastewater treatment. Water use and management, Book II. A Baltic University Programme Publication, Sweden

Mustufa AS, Sulaiman SO, Khudair MY (2013) Application of biofilteration wastewater treatment using Iraqi gypsum and phosphate bio-filters. J Water Resour Hydraul Eng 2(4):149-156

Nag SK, Suchetana B (2016) Groundwater quality and its suitability for irrigation and domestic purposes: a study in Rajnagar Block, Birbhum District, West Bengal, India. J Earth Sci Clim Change 7:2

Nazeer S, Hashmi MZ, Malik RN (2014) Heavy metals distribution, risk assessment and water quality characterization by water quality index of the River Soan, Pakistan. Ecol Indic 43:262-270

Rabeiy RE (2017) Assessment and modeling of groundwater quality using WQI and GIS in upper Egypt area. Environ Sci Pollut R. https://doi.org/10.1007/s11356-017-8617-1

Ramesh K, Elango L (2012) Groundwater quality and its suitability for domestic and agricultural use in Tondiar river basin, Tamil Nadu, India. Environ Monit Assess 184:3887-3899. https://doi. org/10.1007/s10661-011-2231-3

Rana RS, Singh P, Kandari V, Singh R, Dobhal R, Gupta S (2014) A review on characterization and bioremediation of pharmaceutical industries' wastewater: an Indian perspective. Appl Water Sci. https://doi.org/10.1007/s1320101402253

Rasouli F, Pouya AK, Karimian N (2013) Wheat yield and physicochemical properties of a sodic soil from semi-arid area of Iran as affected by applied gypsum. Geoderma 193-194:246-255

Rodier J, Legube B, Merlet N (2009) L'Analyse de l'eau, 9ème édition, Dunod editor
Spitta LF, Diegeler S, Baumstark-Khan C, Hellweg CE (2016) An in vitro approach for water quality determination: activation of $\mathrm{NF}-\kappa \mathrm{B}$ as marker for cancer-related stress responses induced by anthropogenic pollutants of drinking water. Environ Sci Pollut R. https://doi.org/10.1007/s11356-016-7901-9

Stamatelatou K, Frouda C, Fountoulakis MS, Drillia P, Kornaros M, Lyberatos G (2003) Pharmaceuticals and health care products in wastewater effluent: the example of carbamazepine. Water Sci Technol Water Supply 3(4):131-137

The United States Salinity Laboratory Staff (1954) Diagnosis and improvement of saline and alkali soils, USDA agriculture handbook no. 60, US Government

USDA (2017) WQIag-water quality index for runoff water from agricultural fields. Agronomy technical note no 11, Natural Resources Conservation Service, United States Department of Agriculture, March

Venugopalan H (2017) Simplified water quality assurance with UVC led-based sensors in water technology, solutions for industrial water management, Feb 2017, grand view media, Amy Richardson editor

Zhang W, Jin X, Liu D, Tang W, Shan B (2017) Assessment of the sediment quality of freshwater ecosystems in eastern China based on spatial and temporal variation of nutrients. Environ Sci Pollut R. https://doi.org/10.1007/s11356-017-9532-1

Publisher's Note Springer Nature remains neutral with regard to jurisdictional claims in published maps and institutional affiliations. 